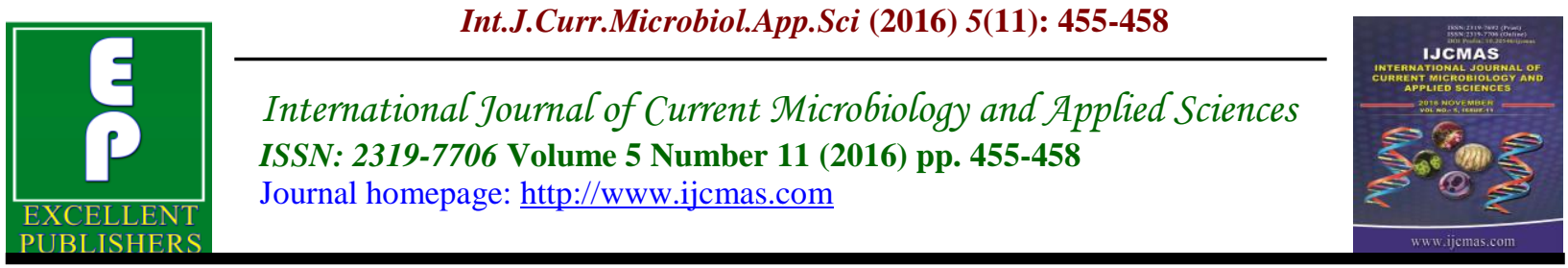

Original Research Article

http://dx.doi.org/10.20546/ijcmas.2016.511.052

\title{
Partial Sequencing of Serendipitously isolated Antifungal Producer, Pseudomonas tolaasii Strain GD76 16s Ribosomal RNA Gene
}

\author{
D.A. Desai ${ }^{1 *}$, G.P. Kukreja ${ }^{2}$, C.J. Raorane ${ }^{1}$ and S. B. Patil \\ ${ }^{1}$ Kankavli College, Kankavli, India \\ ${ }^{2}$ New Arts Commerce \& Science College, Ahmednagar, India \\ *Corresponding author
}

\begin{abstract}
A B S T R A C T
\section{Keywords}

16s r RNA gene,

Pseudomonas tolaasii GD 76.

Article Info

Accepted:

23 October 2016

Available Online:

10 November 2016

Bacteria of the genus Pseudomonas comprise a large group of the active biocontrol strains due to their general ability to produce a diverse array of potent antifungal metabolites. Present study provides partial $16 \mathrm{~S}$ rRNA gene sequence of an antifungal metabolite producer and recently identified Pseudomonas tolaasii GD76; which is serendipitously isolated from a contaminated YPD agar plate on to which it was streaked from casein agar plate where it was showing a pronounced proteolytic activity.
\end{abstract}

\section{Introduction}

Recently, the rise of antimicrobial-resistant bacteria has provided motivation for novel bioactive compound discovery, as it has been recognized by the World Health Organization as a threat to human health (Demain, 1999; Maryna et al., 2007). Among the underexplored bacterial taxa, Pseudomonadales certainly deserve the spotlight (Maryna et al., 2007). Despite being long known as prolific producers of specialized metabolites, their systematic screening has been hampered by difficulties in their cultivation. Bacteria of the genus Pseudomonas comprise a large group of the active biocontrol strains as a result of their general ability to produce a diverse array of potent antifungal metabolites (Ute Hentschel et al., 2002).

\section{DNA extraction and quantification}

DNA Extraction was carried out using HiPurA Bacterial Genomic DNA Purification Kit (Himedia, MB505). Loopful of culture was suspended in $200 \mu \mathrm{l}$ of lysozyme solution $(2.115 \times 106 \mathrm{unit} / \mathrm{ml})$ and incubated at $37^{\circ} \mathrm{C}$ for $30 \mathrm{~min}$. $20 \mu \mathrm{l}$ of RNase A solution was added and incubated for $2 \mathrm{~min}$ at room temperature. Then $20 \mu \mathrm{l}$ of Proteinase $\mathrm{K}$ solution $(20 \mathrm{mg} / \mathrm{ml})$ was added followed by $200 \mu \mathrm{l}$ of lysis solution $\mathrm{C} 1$. The mixture was vortexed and incubated at $55^{\circ} \mathrm{C}$ for $10 \mathrm{~min}$. DNA was precipitated by adding $200 \mu 1$ of ethanol to the lysate and mixed by vortexing. Lysate was then loaded on HiElute Miniprep Spin column and centrifuged at 10,000 rpm for $3 \mathrm{~min}$. Flow 
through liquid was discarded and the column was transferred to new $2 \mathrm{ml}$ collection tube. $500 \mu \mathrm{l}$ of Prewash Solution was then added to the HiElute Miniprep Spin column and centrifuged at $10,000 \mathrm{rpm}$ for 3 minutes. Flow through liquid was discarded and 500 $\mu 1$ of Wash Solution was added to the column. Centrifuged at 10,000rpm for 3 minutes. $200 \mu \mathrm{l}$ of elution buffer was then added to the column and incubated at room temperature for 5 minutes. Centrifuged at $10,000 \mathrm{rpm}$ for 3 minutes. Concentration of DNA was determined using UV-1800 spectrophotometer (Schimadzu Corporation A11454806498). The DNA was stored at $20^{\circ} \mathrm{C}$ for further use. PCR amplification: The DNA isolated from bacteria was subjected to polymerase chain reaction (PCR) amplification using Biometra thermal cycler (T-Personal 48). The PCR reaction mix contained $2.5 \mu \mathrm{l}$ of $10 \mathrm{X}$ buffer, $1 \mu \mathrm{l}$ of each primer, $2.5 \mu \mathrm{l}$ of $2.5 \mathrm{mM}$ of each dNTP, 2.5 Units of Taq DNA polymerase and $1 \mu \mathrm{l}$ Template DNA and $8.5 \mu \mathrm{l}$ nuclease free water. The PCR amplification cycle consist of, a cycle of $5 \mathrm{~min}$ at $94^{\circ} \mathrm{C}$; 35 cycles of $1 \mathrm{~min}$ at $94^{\circ} \mathrm{C}, 1 \mathrm{~min}$ at $50^{\circ} \mathrm{C}, 2 \mathrm{~min}$ at $72^{\circ} \mathrm{C}$; and additionally 1 cycle of $7 \mathrm{~min}$ at $72^{\circ} \mathrm{C}$. The reagents used are procured from GeNei.

\section{Gel electrophoresis}

Gel electrophoresis was performed using $1.0 \%$ agarose (Seakem, 50004L) to analyze the size of amplified PCR product. The size obtained was approx. 850bp for $16 \mathrm{~S}$ rRNA region.

\section{DNA sequencing}

The PCR product was purified using AxyPrep PCR Clean up kit (Axygen, APPCR-50). 100 $\mu 1$ of PCR-A buffer was added to the $25 \mu 1$ of reaction. The sample was mixed and transferred to column placed in $2 \mathrm{ml}$ collection tube and centrifuge at 10,000 rpm for $1 \mathrm{~min}$. the filtrate was discarded.700 $\mu 1$ of W2 buffer was added to the column and centrifuge at 10,000rpm for $2 \mathrm{~min}$. This step was repeated twice. The column was transferred to a new tube. $25 \mu 1$ of Eluent was added into the column and incubated at room temperature for $2 \mathrm{~min}$. Then centrifuge at $10,000 \mathrm{rpm}$ for $5 \mathrm{~min}$. It was further sequenced using Applied Biosystems 3730xl DNA Analyzer USA and chromatogram was obtained. For sequencing of PCR product 519F - 5'CAGCAGCCGC GGTAATAC3' sequencing primer was used.

\section{Bioinformatics analysis}

The DNA sequences were analyzed using online BLASTn (nucleotide Basic Local Alignment Search Tool) facility of National Center for Biotechnology Information (NCBI). The BLAST results were used to find out evolutionary relationship of bacteria. Altogether twenty sequences, including sample were used to generate phylogenetic tree. The tree was constructed by using MEGA 5 software (Felsenstein, 1985; Tamura et al., 2011).

\section{Maximum Parsimony analysis of taxa}

The evolutionary history was inferred using the Maximum Parsimony method. The bootstrap consensus tree inferred from 1000 replicates is taken to represent the evolutionary history of the taxa analyzed. Branches corresponding to partitions reproduced in less than 50\% bootstrap replicates are collapsed. The percentage of replicate trees in which the associated taxa clustered together in the bootstrap test (1000 replicates) is shown next to the branches. The MP tree was obtained using the CloseNeighbor-Interchange algorithm with search level 1 in which the initial trees were obtained with the random addition of sequences (10 replicates). 


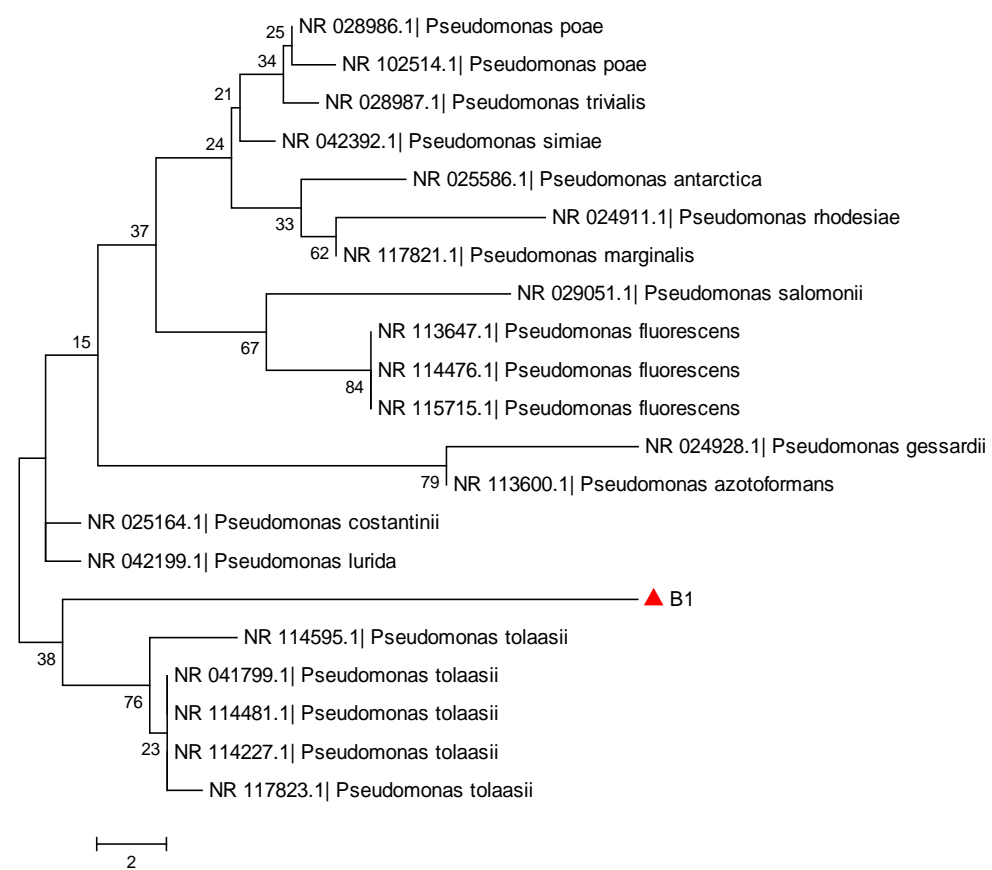

The tree is drawn to scale; with branch lengths calculated using the average pathway method and are in the units of the number of changes over the whole sequence. The analysis involved 21 nucleotide sequences. There were a total of 1542 positions in the final dataset. Evolutionary analyses were conducted in MEGA5.

\section{Nucleotide sequence accession numbers}

This sequence has been deposited at NCBI Nucleotide/ GenBank under the accession no. KU533778. The version described in this paper is the first version, accession no.KU533778.1.

The molecular phylogeny of sample was determined by analyzing $16 \mathrm{~S}$ rRNA gene sequences. On the basis of the position of sequence of the given bacterial samples in the phylogenetic tree, B1 showed closest similarity to Pseudomonas tolaasii.

\section{Acknowledgments}

We thank Principal, New Arts Commerce \& Science College Ahmednagar, MS India, for providing the Microbiological laboratory support. We also thank to Dr. Archana Thakur, and the Codon Bioscience, Panjim Goa India for genome sequencing. We also like to extend our thanks to Miss. Sampada Hajare and Miss. Snehal Rokade to give constant support in entire work.

\section{References}

Demain, A.L. 1999. Pharmaceutically active secondary metabolites of microorganisms. Appl. Microbiol. Biotechnol., 52: 455-463.

Felsenstein, J. 1985. Confidence limits on phylogenies: An approach using the bootstrap. Evol., 39: 783-791.

Maryna, N.M., Emyli, I.K. and Estera, I.D. 2007. Characterization of antimicrobial compounds produce by Pseudomonas aurantiaca S-1. Pol. Jr Microbiol., (56), 245-250.

Moore, E., Arnscheidt, A., Annette, K., Ger, Carsten, S. and Margit, M. 2004. Simplified Protocols for the Preparation of Genomic DNA From bacterial cultures. Mol. Microbial. Eco Man, Second Edition 1.01: 3-18. 
National Centre for Biotechnology Information (NCBI) website.

Nei, M. and Kumar, S. 2000. Molecular Evolution and Phylogenetics. Oxford University Press, New York.

Roemer, T. and Krysan, D.J. 2014. Antifungal drug development: challenges, unmet clinical needs, and new approaches. Cold Spring. Harb. Perspect. Med. 4, 1-14.

Saitou, N. and Nei, M. 1987. The neighborjoining method: A new method for reconstructing phylogenetic trees. Mol. Biol. Evol., 4: 406-425.
Tamura, K., Peterson, D., Peterson, N., Stecher, G., Nei, M., and Kumar, S. 2011. MEGA5: Molecular Evolutionary Genetics Analysis using Maximum Likelihood, Evolutionary Distance, and Maximum Parsimony Methods. Mol. Biol. Evol. (In Press).

Ute Hentschel, Jörn Hopke, Matthias Horn, Anja B. Friedrich, Michael Wagner, Jörg Hacker and Bradley, S. Moore. 2002. "Molecular Evidence for a Uniform Microbial Community in Sponges from Different oceans" Appl. Environ. Microbiol., 68(9):4431. DOI: 0.1128/AEM.68.9.4431-4440. 2002.

\section{How to cite this article:}

Desai, D.A., G.P. Kukreja, C.J. Raorane and Patil, S.B. 2016. Partial Sequencing of Serendipitously isolated Antifungal Producer, Pseudomonas tolaasii Strain GD76 16s Ribosomal RNA Gene. Int.J.Curr.Microbiol.App.Sci. 5(11): 455-458. doi: http://dx.doi.org/10.20546/ijcmas.2016.511.052 